\title{
X-LINKED RECESSIVE FORM OF NEPHROGENIC DIABETES INSIPIDUS IN A 7-YEAR-OLD BOY
}

\author{
Janchevska $\mathrm{A}^{1, *}$, Tasic $\mathrm{V}^{1}$, Gucev $\mathrm{Z}^{1}$, Krstevska-Konstantinova $\mathrm{M}^{1}$, Cheong $\mathrm{HI}^{2,3,4}$
}

\begin{abstract}
*Corresponding Author: Dr. Aleksandra Janchevska, Department of endocrinology and genetics, University Children's Hospital Skopje, Medical Faculty, 1000 Skopje, Republic of Macedonia. Tel: +389-2-3147-474. Fax: +389-2-3129-027. E-mail: dr.sasha1969@yahoo.com
\end{abstract}

\begin{abstract}
Nephrogenic diabetes insipidus (NDI) is caused by the inability of renal collecting duct cells to respond to arginine vasopressin (AVP)/antidiuretic hormone (ADH). We present the case of a 7-year-old boy with a history of excretion of large amounts of dilute urine and polydipsia since infancy. The boy had several vomiting episodes with mild dehydration during the first 3 years of life. There was no evidence of headaches, dizziness or visual problems. He drinks between 2 and 3 L/day and has 24-hour diuresis of 2 liters, now. He has prepubertal appearance with appropriate weight $[+0.85$ standard deviation score (SDS)] and height (+0.15 SDS) for his age. His intelligence was also normal. The water deprivation test showed low urine osmolality after 8 hours of dehydration. After desmopressin administration, urine osmolality remained low. Serum osmolality was in the normal range for sex and age before and after desmopressin administration. This indicated a nephrogenic form of diabetes insipidus. Molecular analyses revealed a P286L [p.Pro(CCC)286Leu(CTC)] mutation in the AVPR2 gene, that was inherited from his mother. This patient is the first case with genetically confirmed

\footnotetext{
${ }^{1}$ University Children's Hospital Skopje, Medical Faculty, Skopje, Macedonia

${ }^{2}$ Seoul National University Children's Hospital, Seoul, Korea

${ }^{3}$ Research Coordination Center for Rare Diseases, Seoul National University Hospital, Seoul, Korea

${ }^{4}$ Kidney Research Institute, Medical Research Center, Seoul National University College of Medicine, Seoul, Korea
}

X-linked inherited form of NDI in the Republic of Macedonia. Molecular analysis confirmed the clinical diagnosis and enabled genetic advice for this family.

Keywords: Nephrogenic diabetes insipidus (NDI), Arginine vasopressin (AVP), Antidiuretic hormone (ADH), Urine osmolality.

\section{INTRODUCTION}

Nephrogenic diabetes insipidus (NDI) manifests as an acquired illness in the majority of patients, but very rarely has a hereditary origin. There are two wellknown hereditary forms of NDI, type 1 and type 2. The majority of patients (about $90.0 \%$ ) have type 1 , an X-linked recessive form of NDI caused by mutations in the AVPR2 gene encoding the vasopressin $\mathrm{V} 2$ receptor. The patients are predominantly males, but women are healthy or asymptomatic carriers. The remaining $10.0 \%$ of patients carry type 2 , autosomal NDI. This type is caused by the aquaporin- 2 water channel (AQP2) gene mutations [1].

Nephrogenic diabetes insipidus is caused by the inability of renal collecting duct cells to respond to antidiuretic action of arginine vasopressin (AVP). This antidiuretic hormone (ADH) action in kidneys is regulated by three subtypes of $G$ protein coupled AVP receptors. The V1A and V1B type receptors act through $\mathrm{Gq}$ proteins and the phospholipase $\mathrm{C}$ activation system, but $\mathrm{V} 2$ receptor acts through adenyl cyclase and Gs proteins activation system [2-4]. Renal collecting duct cells cannot reabsorb the water and the kidneys produce a large amount of low concentrated 
urine as a result of mutations of the AVPR2 gene in type 1 NDI patients.

\section{CASE REPORT}

We present the case of a 7-year-old boy, the third child in a family of healthy, non consanguineous parents. His two older sisters are also healthy. Our patient has a history of excretion of large amounts of dilute urine and polydipsia since infancy. He had several vomiting episodes with mild dehydration during the first 3 years of life. There was evidence of headaches, dizziness or visual problems.

The boy drinks between 2 and $3 \mathrm{~L} /$ day and has 24-hour diuresis of $2 \mathrm{~L}$. He has prepubertal appearance with an appropriate weight $[+0.85$ standard deviation score (SDS)], 75th percentile and height $(+0.15$ SDS $), 50$ th percentile at the growth curve, for his age (Figure 1). His intelligence was also normal.

Random serum sodium level was $154.0 \mathrm{mmol} / \mathrm{L}$ and serum osmolality was $296.0 \mathrm{mOsm} / \mathrm{kg}$, but urine osmolality was $46.0 \mathrm{mOsm} / \mathrm{kg}$. A measurement of AVP was not available and kidney ultrasound was uneventful. A water deprivation test showed very low urine osmolality after 8 hours of dehydration. After desmopressin administration, urine osmolality

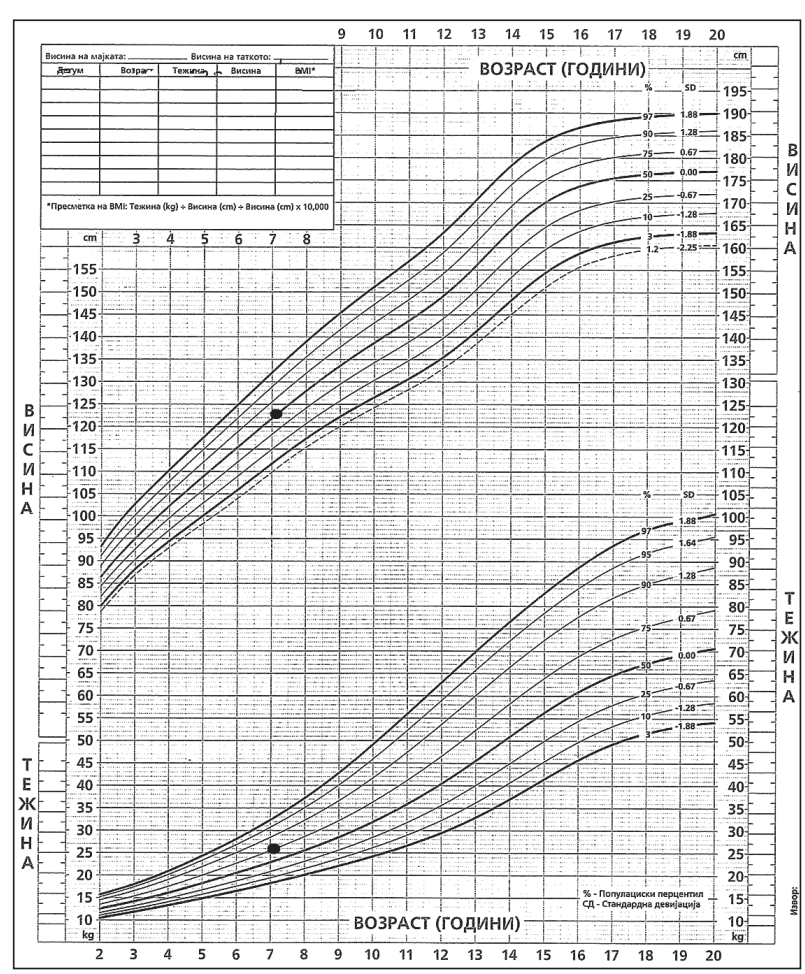

Figure 1. Patient's growth chart. still remained low. Serum osmolality was in normal range for sex and age before and after desmopres$\sin$ administration. Serum sodium values after water deprivation were also in upper normal range, 147.0 $\mathrm{mmol} / \mathrm{L}$. This indicates a nephrogenic form of diabetes insipidus.

Molecular analyses showed two non synonymous variants (p.R106H and p.P286L) and both were inherited from his mother. The first is a hemizygous c. $317 \mathrm{G}>\mathrm{A}$ variant in exon 2 of $A V P R 2$ [p. $\operatorname{Arg}(\mathrm{CGT}) 106 \mathrm{His}(\mathrm{CAT})]$, and the second is also a hemizygous c. $857 \mathrm{C}>\mathrm{T}$ variant in exon 2 of $A V P R 2$ [p.Pro(CCC)286Leu(CTC)] (Figure 2). In silico analysis predicted that only p.P286L was a pathogenic mutation. Also, only the p.P286L mutation is known to have an evolutionary conserved residue. This non synonymous (missense) p.P286L mutation is pathogenic for our patient and results in clinically evident NDI.

Treatment includes high volumes of liquids and low salt intake. These nonspecific measures are useful to avoid dehydration and to maintain adequate fluid balance.

\section{DISCUSSION}

Males of various age groups are affected with type 1 NDI $[5,6]$. In a study of 30 Dutch patients with NDI, $87.0 \%$ were diagnosed during the first 2.5 years of life [7]. Severity of the disorder differs from mild form with polyuria and polydipsia to severe dehydration crisis with anorexia, failure to thrive, fever and constipation. Females are usually healthy or asymptomatic carriers [7]. Recently, Hong et al. [8] reported one girl among 24 boys in a cohort of 25 children with NDI. It was explained that she was analyzed separately and inactivation and mosaicism of the X chromosome may influence clinical manifestations in female patients [8]. Our boy had a few episodes of mild dehydration during the first 3 years of life, but after that, he was well hydrated despite large amounts of excreted dilute urine.

Most of the patients with NDI grow up below the 50th percentile at the growth curve, but gained weight after years of life with low body weight. The index patient had an appropriate weight $(+0.85 \mathrm{SDS})$ at 75 th percentile, and height $(+0.15$ SDS $)$ at 50th percentile at the age of 7 years. Although the children with X-linked NDI were expected to be mentally retarded as a result of dehydration in early childhood, 

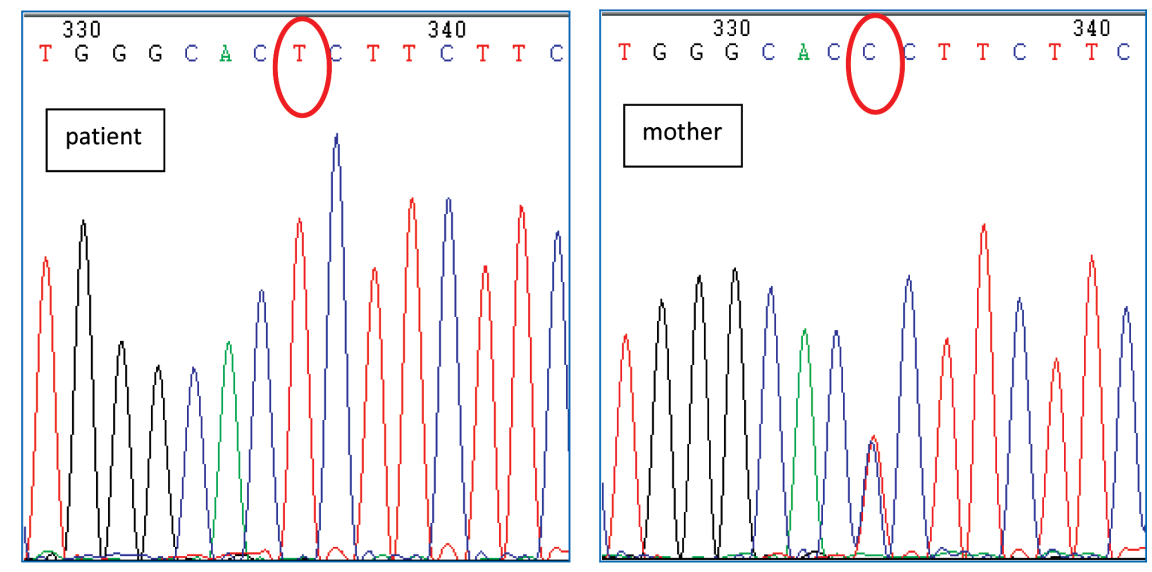

Figure 2. Molecular analysis of the p.P286L mutation.

the majority have normal intelligence. Our patient also has normal intelligence.

Children with NDI usually do not have urinary tract anomalies or infections. Van Lieburg et al. [7] reported two patients with severe hydronephrosis and small rupture of the urinary tract due to minor trauma and an additional two patients had episodes of acute urine retention. Urinary tract malformation or infection was not detected in our patient.

The gene that encodes V2 receptors was mapped at chromosome Xq28 by Seibold et al. [9]. It spans $2.2 \mathrm{kB}$ and contains three exons and two small introns (MIM 300538). The majority of mutations disable the receptor reaching the plasma membrane, but rarely, the receptor cannot bond with the vasopressin or may cause stop trig-gering the cAMP signal $[10,11]$.

The AVPR2 gene mutations associated with $\mathrm{X}$ linked NDI was first detected by van den Ouweland $e t$ al. [12] in 1992. Thereafter, many mutational reports followed [13-17], and at the moment, a total of 254 different mutations in the AVPR2 gene are listed in an online database site, $\mathrm{HGMG}{ }^{\circledR}$ Professional 2014.1 (http://www/hgmd.cf.ac/il/ac/search.php), including 134 missense mutations, 21 non-sense mutations, 49 small deletions, 22 large deletions, 15 small insertions, five small indels, four complex rear-rangements and one large insertion/duplication.

Molecular analyses of our patient showed two non synonymous (missense) variants. The first is a hemizygous c. $317 \mathrm{G}>\mathrm{A}$ variant in exon 2 of $A V P R 2$ [p. $\operatorname{Arg}(\mathrm{C} G \mathrm{~T}) 106 \mathrm{His}(\mathrm{C} A \mathrm{~T})]$, and the second is also a hemizygous c. $857 \mathrm{C}>\mathrm{T}$ variant in exon 2 of $A V P R 2$ [p.Pro(CCC) 286Leu(CTC)]. Both variants have segregation in the family. They were inherited from his mother. She is an asymptomatic carrier. A hemizygous c. $317 \mathrm{G}>$ A mutation (p.R106H) is not listed in the latest version of HGMG ${ }^{\circledR}$ Professional. However, a different mutation at this residue (R106C) was reported by Bichet et al. [14] in 1994. The second hemizygous c.857C $>$ T mutation (p.P286L) was reported by Bichet et al. [10] in 1998. The in silico analyses showed abnormal scores only for the p.P286L mutation. Also, only the p.P286L mutation is known to have an evolutionary conserved residue. Although we could not perform functional studies, we indirectly confirmed that a non synonymous p.P286L mutation is pathogenic for our patient and resulted in NDI.

Knowing the receptor action caused by an identified mutation in the $A V P R 2$ gene or carrier, may help physicians to provide adequate care and treatment to patients with NDI $[10,16,18,19]$. The aim of treatment of NDI patients is to ensure proper fluid balance and to avoid mental retardation due to severe dehydration, especially in the neonatal period and early infancy. This would be achieved with high volumes of fluids and low salt food followed by hydrochlorothiazide or amiloride treatment. Indomethacin may also be useful [20-22]. In addition, a novel therapeutic approach of rescuing mutant AVPR2 using chemical or pharmaceutical chaperones has been studied [23-29].

\section{CONCLUSIONS}

We report the case of a 7-year-old male patient, the first case with a genetically confirmed X-linked form of NDI in the Republic of Macedonia. Molecular analysis confirmed the clinical diagnosis and enabled 
genetic advice for this family. Female relatives in a family with an NDI patient should be recommended for molecular carrier testing and should be aware of the possibility of bearing a male offspring with NDI. This implicates the importance of prenatal diagnosis and its impact on the quality of life in children.

Declaration of Interest. This study was supported by a grant from the Korean Health Technology R\&D Project, Ministry of Health and Welfare, Republic of Korea (A120017). The authors report no conflicts of interest. The authors alone are responsible for the content and writing of this article.

\section{REFERENCES}

1. Morello JP, Bichet DG. Nephrogenic diabetes insipidus. Annu Rev Physiol. 2001; 63: 607-630.

2. Birnbaumer M. Vasopressin receptors. Trends Endocrinol Metab. 2000; 11(10): 406-410.

3. Schöneberg T, Kostenis E, Liu J, Gudermann T, Wess J. Molecular aspects of vasopressin receptor function. Adv Exp Med Biol. 1998; 449: 347-358.

4. Robert J, Clauser ER. Vasopressin receptors: Structure/function relationships and signal transduction in target cells. J Soc Biol. 2005; 199(4): 351-359.

5. Cannon JF. Diabetes insipidus: Clinical and experimental studies with consideration of genetic relationships. Arch Intern Med. 1995; 96: 215-272.

6. Nakano KK. Familial nephrogenic diabetes insipidus. Hawaii Med J. 1969; 28: 205-208.

7. van Lieburg AF, Knoers NVAM, Monnens LAH. Clinical presentation and follow-up of 30 patients with congenital nephrogenic diabetes insipidus. J Am Soc Nephrol. 1999; 10(9): 1958-1964.

8. Hong CR, Kang HG, Choi HJ, Cho MH, Lee JW, Kang JH, et al. X-linked recessive nephrogenic diabetes insipidus: a clinicogenetic study. J Pediatr Endocrinol Metab. 2014; 27(1-2): 93-99.

9. Seibold A, Brabet P, Rosenthal W, Birnbaumer M. Structure and chromosomal localization of the human antidiuretic hormone receptor gene. Am J Hum Genet. 1992; 51(5): 1078-1083.

10. Bichet DG, Turner M, Morin D. Vasopressin receptor mutations causing nephrogenic diabe- tes insipidus. Proc Assoc Am Physicians. 1998; 110(5): 387-394.

11. Bichet DG. Nephrogenic diabetes insipidus. Adv Chronic Kidney Dis. 2006; 13(2): 96-104.

12. van den Ouweland AMW, Dreesen JCFM, Verdijk M, Knoers NVAM, Monnens LAH, et al. Mutations in the vasopressin type 2 receptor gene (AVPR2) associated with nephrogenic diabetes insipidus. Nat Genet. 1992; 2(2): 99-102.

13. Wildin RS, Antush MJ, Bennett RL, Schoof JM, Scott CR. Heterogeneous AVPR2 gene mutations in congenital nephrogenic diabetes insipidus. Am J Hum Genet. 1994; 55(2): 266-277.

14. Bichet DG, Birnbaumer M, Lonergan M, Arthus MF, Rosenthal W, Goodyer P, et al. Nature and recurrence of AVPR 2 mutations in X-linked nephrogenic diabetes insipidus. Am J Hum Genet. 1994; 55(2): 278-286.

15. Tsukaguchi $\mathrm{H}$, Matsubara $\mathrm{H}$, Taketani $\mathrm{S}$, Mori Y, Seido T, Inada M. Binding, intracellular transport, and biosynthesis-defective mutants of vasopressin type 2 receptor in patients with $\mathrm{X}$-linked nephrogenic diabetes insipidus. J Clin Invest. 1995; 96(4): 2043-2050.

16. Cheong HI, Park HW, Ha IS, Moon HN, Choi Y, Ko KW, et al. Six novel mutations in the vasopres$\sin \mathrm{V} 2$ receptor gene causing nephrogenic diabetes insipidus. Nephron. 1997; 75(4): 431-437.

17. Carroll P, Al-Mojalli H, Al-Abbad A, Al-Hassoun I, Al-Hamed M, Al-Amr R, et al. Novel mutations underlying nephrogenic diabetes insipidus in Arab families. Genet Med. 2006; 8(1): 443-447.

18. Bichet DG. Molecular and cellular biology of vasopressin and oxytocin receptors and action in the kidney. Curr Opin Nephrol Hypertens. 1994; 3(1): 46-53.

19. Bichet DG. Pathological aspects of water transport in the collecting ducts. Nephrologie. 1996; 17(7): 417-422.

20. Alon U, Chan JCM. Hydrochlorothiazideamiloride in the treatment of congenital nephrogenic diabetes insipidus. Am J Nephrol. 1985; 5(1) 9-13.

21. Libber S, Harrison H, Spector D. Treatment of nephrogenic diabetes insipidus with prostaglandin synthesis inhibitors. J Pediatr. 1986; 108(2): 305-311. 
22. Morin D, Delenne AL, Kervran A. Congenital nephrogenic diabetes insipidus. Arch Pediatr. 2005; 12(1): 59-66.

23. Cheong HI, Cho HY, Park HW, Ha IS, Choi Y. Molecular genetic study of congenital nephrogenic diabetes insipidus and rescue of mutant vasopressin V2 receptor by chemical chaperones. Nephrology. 2007; 12(2): 113-117.

24. Los EL, Deen PM, Robben JH. Potential of nonpeptide (ant)agonists to rescue vasopressin V2 receptor mutants for the treatment of X-linked nephrogenic diabetes insipidus. J Neuroendocrinol. 2010; 22(5): 393-399.

25. Bockenhauer D, Carpentier E, Rochdi D, van't Hoff W, Breton B, Bernier V, et al. Vasopressin type 2 receptor $\mathrm{V} 88 \mathrm{M}$ mutation: Molecular basis of partial and complete nephrogenic diabetes insipidus. Nephron Physiol. 2010; 114(1): 1-10.

26. Ranadive SA, Ersoy B, Favre H, Cheung CC, Rosenthal SM, Miller WL, et al. Identification, characterization and rescue of a novel vasopres- sin-2 receptor mutation causing nephrogenic diabetes insipidus. Clin Endocrinol (Oxf). 2009; 71(3): 388-393.

27. Robben JH, Deen PM. Pharmacological chaperones in nephrogenic diabetes insipidus: Possibilities for clinical application. BioDrugs. 2007; 21(3): 157-166.

28. Robben JH, Sze M, Knoers NV, Deen PM. Functional rescue of vasopressin $\mathrm{V} 2$ receptor mutants in MDCK cells by pharmacochaperones: Relevance to therapy of nephrogenic diabetes insipidus. Am J Physiol Renal Physiol. 2007; 292(1): 253-260.

29. Morello JP, Salahpour A, Laperrière A, Bernier $\mathrm{V}$, Arthus MF, Lonergan M, et al. Pharmacological chaper-ones rescue cell-surface expression and function of misfolded V2 vasopressin receptor mutants. J Clin Invest. 2000; 105(7): 887-895. 